\title{
THE GUILD OF ST. BARNABAS
}

\author{
IN CIILRE: OF
}

S. M. DURAND

Puble Librery, Boiton

\section{구룰}

OnAxoE, N. J.-April las been a somenlut busy montl with us. 'To login at the end of things nud go backward, the regnlar service and meeting was held on the 28th at the Chureli of the Iloly Commmion, Sonth Ornuge. A special cill had been made for n goos ittendance, bnt, unfortunately, it poured rilin, whieh prevented many from being present. Isy previons arrangements we lad the pleasure of greeting Dr. Schdhler, from lkrooklyn, who eame, us lie cxpressed it, to " sonk In" information alout the scheme which had becn mede' distonsion at the Generul Conncil. We feared that the inhospitable rain was the most thorough soaking he wus likely to oblain, us we issembled rntler for further disenssion of the "lRelicf" selieme, than to give any more detailed plin of exertltlon. We feel very keculy that some well-ilefined plan sheuld be afoot for tho relief of tho nurso when sho falls on evil duys, but time and unch thenght will be eonsumed before the venture enn be mude, assmred thongl we ure thit it is a thing that will surely be accomplished. The ladies of the ehureh gave a pleasumt reeption at the elese of the jueetlong ant we wished the time latd been twies as leng. On Saturday, April 10, slr. Komuld Grunt gave an ergan recitul ut Grace Chureh, hls selections belng greatly enjoged by ull who were able to be present. The sewing meeting lield at the Training. Seliool on April it was notod as having been the best nttended of nny ln the series and uneli work was necoun. plished. Aprll 7 will be remembered us the date of a delightful reception given by Mrs. Willian Il. Willians at lee residence, 308 kissex Avenue. Suceral of the assoelates reecived with her, aud a lurge number of nurses aviled themselves of tho hours from four to six to enjoy her hospitality und the pleasuro of uneetlug one another, whieh, indeel, is not the least nttractire part of these sociul gatlerings.

Bostox.-'The April meeting of the Boston Brnel was held at St. Andrew's Clureh on the evening of the 27 th. Owing to the inclemency of the weatler the attendance was not large, but the oceasion wis rery elicerful uml pleusant, and all were glad to weleouse Mliss Shurray nnd henr of her mission work nt W'hite kocks. It has alrendy been related in former notes how Indian babies are resened from being buried with their mothers, anl Mliss Mnrrigy brought with her on her trip Enst one of these sturdy survivors, who will awnken interest in all who see him. 'Ihe resignations of three associntes were regretfully necepted. Mr. Kidner, the rector of St. Andrews, presidel in Mr. Bishop's absence. The present week, and, indeed, this whole month, is full of festivals, ns the "great forty days" ends with Ascension Day, falling this year ou Mluy 12, nnd the feasts of Whitsunlay and Trinity Sunday also oceur in May. It may interest seme of the nurecs in Boston to henr about the Patromal Festival of St. John tho Esangelist, which is this week being eclebrated at St. John's, Bowdoin Street. 'There are a 
gaad unany nurses in thls cangregatlon, nnd we hape many af them wero present last Sunday. After the pracessian and singing af the liy'mu, "Glorions City, Ifearenly Saleni," the rectar, Father Osborne, preached an the life of St. Jahn the Wrangelist, saying that the inain lesson ta bo drawn from the lieroie lnbars af this "belared apostle" was that thraugh sacrifiee he attained ta the Bentifie Visian. This sacriflee was nat a grudging ane, but was entered lnta and earried au In sueb a perfect unian with bla Naster that it secmed the mast slniple and uatural thing to da. St. Jalın dld nat, even in the begimnlug, questian and warry, nar did he ask ta see the whale af hia task, ar even the end of It. Befare he was ealled ta be one of the twelve he dld what hls father had braught line up to do,- - that is, he fallawed the simple enllung of a figherman, - and when the Afaster's raice bade hlm "Fallaw ue," he still abeyed that higher eall, gaing an "frou strengtlı to strengtl?" with the saine unquestianing falth aud obedience. In hls persecutians, hia trial of expected martyrdom, hls exile hn Patinos, and, finally, in his lang and lanely blshaprie at Ejplesus, where he was kept an earth so many years after lils beloved fellawapastles had gane befare, the splrit af laving submission was still the same. Ta enter inta and understaud this spirlt is the Clirlstian'a surest safeguard in trlal and temptatlau. In tho world we must have tribulation, we all know this, but to taste the sweetness of saerineo ls only giveu to those who, like the beloved Joln, slmply, day by day, follow the IIlgher Will, whlele leads them, slowly, palnfully perhaps, but surely und safely, to the attainment of thelr lilghest hopes and dearest asplra. tions. These lessons aro thase that come home to us all the mare nearly when we think of our own festlinal of St. Baruabas, with lts message af lavhg serviee, and we hope that we may kecp It in joy and gladness, feeling the greatness of our gift of merey-that quallty whlel is "twlee blest," ns "blessing lim that gives and hlm that takes."

Brookrys,-At the Mfareh meeting of the Brooklyn Branch of the Guild of St. Barnabas the taple af diseusslan was that of the mlssianary nurse. After considering the questlan earefully, it was decided ta present it again at the next meeting in arder ta learn the mind of the unjarlty; the resolutlan passed at the counell in Ilartfard laving been read by the chnplaln. Another tapie af lnterest was same menns of Inereasing the building fund. Miss Sutlife, wha far eigliteen years has filled the aftice af superintendent af the Iong Island Callege Jospital, will retlre an Mfay $l$ and take up ler residence in South Narwalk, Conn. Three of the nurses, who have flled the term of twenty-one, twelve, and nine yenrs respectlvely, have alsa resigned their pasitlans, and twa of them havs apened a nurses' hause a shart distanee from the haspital. One af the members present gave an interesting aecount af her three manths af duty nt Butler, Pn., durlng the typhoid epldemle. She said one could nat speak toa highly af the ehairman of the comnuittec, Mr. J. N. Moore, a lawjer, wha gave up lis buslnes and warked day and nlght far the publie good; be shawed a wanderful talent far remembering the minutest details, and could enll each incmber by name, and made it his duty to pravide far the speein] necessitles of each one, earcfully pieking up the threads and converting the whole inta a magnifiecnt picce af wark. The nurses were given eamfortnlle, elean beds in a large dormitary, and meals were pravided three times $n$ day by the ladies of the Second Presbyterian Church; night suppers were alsa provided upon npplicatian of thase requiring the same, and free transportation over the Baltlmare and Ohlo Railraad to their homes. 
It was not only the unrses who were so well eared for, but the people at large, ricli anul poor olike. "lhe umres in many instances rumoines on duty for forty. cight lours. 'lite work was not confincd to the epjilemic alonc, but variens dlsenses developing in the same family were trented in like manuer, as well as the complientions arising. Ono instance eited wus tlot of n consmmptive mun, whose wihele houschold were allacked wilh typhoid. Ihe lielief Committec look charge, fanying all expenses, cven to that of proviling a servont. One menber dicd, but the man survived. Food, bedfing, clothing, delicacies, and eren presents for fanilies were pajd for by the sanc. One cuse was reported us huving five reinfectlons; another, after a normal temperature of twelve days, has:inu' rinin. feeted, und two murses were iletuiled under the strietest tare. Oue Water Con. pany sent two carlonis of pute water. The amount of water consinmed uny be julged when it is mulerstool that the Itelief Committee paid one thonsand dollars tor the return of water lottles. I'le State formished all disinfectunts. 1)r. Batt personally condueted thiB matter. liaeh uurse is to rcceive un engraved certiti. cate, whleh will be grently upprecinted.

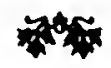

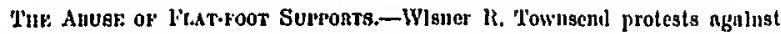
tho too common luabit of treating Itat-fool by viuriuns forms of smpport withont consulthing a surgeon. Firrors in dingnosls are ensily made, and ostitis of tarsus or aukle, melntarsnlgia, neurnlgin, or nu intlaumatory coucretion of the parts about the luner side of the foot luve been mistiken for flat-foot. In one coso a sarcomn of the sole of tile foot was trentell for some time by braces. More. over, when llat-foet exists, it docs noL necessarily follow that a support must be applied, for there are contraindications known to the profession, suels as exlreme spasm, extreme teformity, or Inflamumtory condltons. Suotlier dnmage result. ing from the budiscriminate use of sipports is that mauy cases, milu lo type aul enslly eured by medien unen, are nllowed to grow worse, and the patient mny becoune so seriensly erlppled that operntion may be needed, or the case be ineurable. 'I'he supports muy sot fit, may not sulplort at ull, and tuny increase, or even proilnee, deformity. Silpports bought by the patient wio is his own murgeon canuot le suitable when the prineiples of the disense are not understood.Americon Jonrnal of Orthopadio Surgcry.

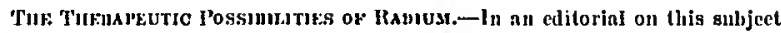
the Boston If cdical and Surgical Jonruol silys in the Brilish If cdicol Journol MIr. John Machntyre writes brictly in continuation of a frevions article on work whịg ho has done. He found that lupuns and rodent ulcers were very favorably afteeted by exposure to the rays of radimn. Mr. Frederic Sodily suggests the posstbillty of applying the rays of ralium and thorimu to the treatment of con. sumpition. The theory being that inlahation of radimu solution gives rise to the formation of a fihu of radio-active matter which persists for a certain definite tlme, It is eonceived possible that radimu wonld continue to excrt its activity in the air.cells of the patient's lungs after the emanatlons themselves had been exhalcd. 